International Journal on Biological Sciences 12 (1), January-June 2021, pp 8-12 https://doi.org/10.53390/ijbs.v12.i1.2

ISSN No.: 0976-4518

\title{
IMPACT OF THE SUBLETHAL CONCENTRATIONS OF CYPERMETHRIN TOXICITY ON NITROGEN METABOLISM IN FRESH WATER FISH HETEROPNEUSTES FOSSILIS
}

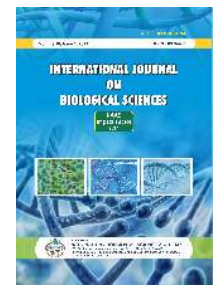

\author{
R. Nigar Sulthana \\ SPW Degree \& PG College \\ Tirupati, Chittoor Dt. Andhra Pradesh, India
}

\section{Review Paper}

Received: 14.02.2021

Revised: 20.02.2021

Accepted: 26.02.2021

\begin{abstract}
Cypermethrin is a synthetic pyrethroid pesticide $\left(\mathrm{C}_{22} \mathrm{H}_{19} \mathrm{Cl}_{2} \mathrm{NO}_{3}\right)$ that has shown effective impact of strong pesticidal activity observed in Heteropneustes Fossils, a fresh water fish exposed to sublethal concentrations of cypermethrin in different tissues liver, gill, and muscle for 4 and 7 seven days. The enzyme activity of Glutamate Dehydrogenase (GDH) was increased all the tissues especially in liver and gill. Significant change might be attributed to tissue change under toxic stress in Heteropneustes fossils. The increased levels of Urea and Ammonia also noticed indicate remarkably the role as biomarkers of cypermethrin toxicity. And the raise in Ammonia as well as urea levels indicates the concentration and tissue dependent which in turn helps to assess the impact of synthetic pyrethroids on the fish. The changes in Ammonia and Urea levels is often be reflected in nitrogen metabolism and interdependent biochemical reactions.
\end{abstract}

Keywords: Cypermethrin, Heteropneustes fossils, Glutamate dehydrogenase, Urea, Ammonia.

\section{INTRODUCTION}

Synthetic Pyrethroids considered to be an effective insecticides in Agriculture and Aquaculture due to their high insecticidal toxicity with low mammalian toxicity (Elliot et al., 1974) and easily biodegradable. These insecticides occur by ingestion of contaminated food uptake of waterborne residue and through the integument of observed material (Kerr \& vas (1973). The uptake of insecticide in fish was reported to be usually, mostly through the gills (Holden, 1962; Addison, 1976). Fish-specific organs such as the gills and their late metabolic action against this type of pesticide make fish highly susceptible to the toxicity of pyrethroid pesticides. Oxidative stress plays an important role in the neurological, reproductive and developmental toxicity caused by pyrethroids. Moreover, changes in antioxidant enzyme activity following pyrethroid pesticide exposure make fish more susceptible to oxidative stress caused by environmental pollutants. In this an attempt was made to examine occurrence of pyrethroid pesticides in the aquatic environment and oxidative stress induced toxicity in fish exposed to pyrethroids.

\section{MATERIALS AND METHODS}

Heteropneustes fossils were collected from surrounding tanks of Kakinada, Andhra Pradesh and transferred to large drum and are maintained in spacious tanks and were acclimatized. They were fed daily with meat and liver of chicken. Afterwards the fish were exposed to according to their biomass ratio (Dondoroff et al., 1951) to different concentrations of cypermethrin.

The $\mathrm{LC}_{50}$ was determined $(65 \mu \mathrm{g} / \mathrm{l} / 48 \mathrm{~h})$ tenfold lower concentration of the $\mathrm{LC}_{50}$ was selected as sub lethal concentration $(0.52 / 65 \mu \mathrm{g} / \mathrm{L})$ and the fishes were exposed to 4 days and 7 days. Controls were maintained

*Corresponding author: nigar2301@gmail.com 
simultaneously. After the stipulated period, the fishes were sacrificed and the tissues namely liver, brain, muscle and gill were isolated in cold conditions to analyze various parameters.

Glutamate dehydrogense was assayed by the method of Lee and Hardy (1965). GDH activity was expressed as $\mu \mathrm{m}$ formozan formed/mg protein /h. The experiments were repeated for 6 times to get the concurrent values. Ammonia content was estimated by the method given in Natelson (1971), urea content was estimated by diacetyl monoxime method recommended by Natelson (1971), was followed for the colorimetric assay of acid and alkaline phosphates.

Table 1: Showing the Glutamatedehydrogenase, ammonia, urea levels in different tissues of control and cypermethrin exposed fish, Heteropneustes fossilis, values are Mean \pm S.D of six individual observations. "Significant at $\mathbf{P}<0.001$, Significant at $\mathbf{P}<0.05{ }^{* * *}$ Significant at $\mathbf{P}<0.01$.

\begin{tabular}{|c|c|c|c|c|c|}
\hline \multirow[t]{3}{*}{1} & \multirow[t]{3}{*}{ Glutamate Dehydrogenese } & $\begin{array}{l}\text { Name of the tissue } \\
\text { Liver }\end{array}$ & $\begin{array}{c}\text { Control } \\
\begin{array}{c}0.420 \\
\pm 0.003\end{array} \\
\end{array}$ & $\begin{array}{c}4 \text { days } \\
0.443^{* *} \\
\pm 0.004 \\
(5.47) \\
\end{array}$ & $\begin{array}{c}7 \text { days } \\
0.552 * * * \\
\pm 0.003 \\
(31.42)\end{array}$ \\
\hline & & Muscle & $\begin{array}{c}0.175 \\
\pm 0.001\end{array}$ & $\begin{array}{l}0.210 * \\
\pm 0.002 \\
(20.00)\end{array}$ & $\begin{array}{l}0.232 * \\
\pm 0.003 \\
(32.57)\end{array}$ \\
\hline & & Gill & $\begin{array}{c}0.130 \\
\pm 0.003\end{array}$ & $\begin{array}{l}0.254 * * \\
\pm 0.009 \\
(95.38)\end{array}$ & $\begin{array}{c}0.273 * * * \\
\pm 0.010 \\
(110.0)\end{array}$ \\
\hline \multirow[t]{3}{*}{2.} & \multirow[t]{3}{*}{ Ammonia } & Liver & $\begin{array}{c}12.30 \\
\pm 0.172\end{array}$ & $\begin{array}{l}14.10 * * \\
\pm 0.135 \\
(14.63)\end{array}$ & $\begin{array}{l}19.32 * * \\
\pm 0.152 \\
(57.07)\end{array}$ \\
\hline & & Gill & $\begin{array}{c}11.03 \\
\pm 0.127\end{array}$ & $\begin{array}{c}12.40 * * * \\
\pm 0.142 \\
(12.42)\end{array}$ & $\begin{array}{l}16.10 * \\
\pm 0.17 \\
(45.96)\end{array}$ \\
\hline & & Muscle & $\begin{array}{c}6.93 \\
\pm 0.178\end{array}$ & $\begin{array}{l}7.210 * * * \\
\pm 0.145 \\
(4.040)\end{array}$ & $\begin{array}{l}7.950 * * \\
\pm 0.114 \\
(14.71)\end{array}$ \\
\hline \multirow{3}{*}{3.} & \multirow{3}{*}{ Urea } & Liver & $\begin{array}{c}7.601 \\
\pm 0.230\end{array}$ & $\begin{array}{l}9.601 * \\
\pm 0.841 \\
(26.31)\end{array}$ & $\begin{array}{l}13.620 * \\
\pm 0.670 \\
(79.18)\end{array}$ \\
\hline & & Gill & $\begin{array}{l}3.015 \\
\pm 0.42\end{array}$ & $\begin{array}{l}4.121 * \\
\pm 0.120\end{array}$ & $\begin{array}{c}5.105^{*} \\
\pm 0.266\end{array}$ \\
\hline & & Muscle & $\begin{array}{c}4.012 \\
\pm 0.120\end{array}$ & $\begin{array}{l}5.360 * \\
\pm 0.201 \\
(36.68)\end{array}$ & $\begin{array}{l}6.805 * \\
\pm 0.260 \\
(69.61)\end{array}$ \\
\hline
\end{tabular}

\section{RESULTS AND DISCUSSION}

The present results show that cypermethrin induced alterations are tissue - specific and the activity of enzyme Glutamate Dehydrogenase, Ammonia and Urea levels have shown significant elevation in all tissues of fish exposed to sublethal concentrations of cypermethrin for 4 days and 7 days.

\section{Glutamate Dehydrogenase:}

GDH activity showed variations in different tissues of fish exposed to sublethal concentration of cypermethrin for 4days and 7 days (Table 1). Under the impact of cypermethrin the GDH activity showed significant $(\mathrm{p}<0.001)$ increase in all the tissues. The increase in GDH activity in the tissues provided 
ketoglutarate and reduced nucleotides, which may fulfil the energy requirements during toxicity manifestations (Chandravathy and Reddy, 1994). GDH is also known to play a crucial role in Ammonia metabolism and is known to be affected by a variety of effectors (Shakori et al., 1976, David, 2004).

During the metabolic functions with great physiological significance are known to be closely associated with the detoxification mechanisms of tissues. GDH in extra hepatic tissue could be utilized for its ultimate detoxification to Urea in the liver. The increase in GDH indicates response to toxic stress. This shows that oxidative deamination contributes to higher Ammonia production. The high levels of Ammonia produced is not eliminated but salvaged through GDH activity. The GDH activity increases in all tissues suggest the possibility of a need for $\alpha$ Ketoglutarate to TCA cycle for the liberation of energy.

In this present study, the GDH activity showed a progressive enhancement in all tissues (gill, muscle and liver) throughout the exposure suggesting a need for $\alpha$-Ketoglutarate. GDH catalyzes the reversible reaction of oxidative deamination of glutamate to $\alpha$ Ketoglutarate and Ammonia (Prasad T.A, T. Srinivas and C. Reddy 1991) plays an important role in the Catabolism and biosynthesis of amino acid. GDH activity was increased in muscle and liver tissues for 7 days under Cypermethrin toxicity, which indicates increased deamination of glutamate and formation of Ammonia. It has been observed that the sublethal exposure of cypermethrin produced less change in the protein metabolism. It has also been noticed that the liver, gill and muscle were affected and the disturbances were found to be more in those tissues than that of muscle tissue.

\section{Ammonia}

Ammonia is a toxic product in the nitrogen metabolism for which the living cells are quite sensitive. Increased Ammonia formation leads to depletion of $\alpha$ Ketoglutarate resulting in the impairment of TCA cycle and subsequent decrease in the energy synthesis (Bessaman and Bessaman, 1955). The increased levels of Ammonia are obtained in different tissues like gill, liver and muscle exposed to sublethal concentrations of cypermethrin (Table 1). In control fish the more ammonia content was noticed in liver followed by muscle and gill., which suggests that liver is the target organ for detoxification of Ammonia and the other tissues showed less involvement in nitrogen metabolism. The increased levels of Ammonia showed significant levels in different tissues of fish expose to cypermethrin for 4 days and 7 days .

The elevation in the levels of Ammonia increases the levels of protein hydrolysis, as Ammonia is the main product of protein catabolism (Campbell, 1973). Both transamination and deamination are boosted up adding more Ammonia to the existing level. Elevation in Ammonia levels is the reaction of the transamination under pesticidal impact (Kabeer, 1979) was reported to augmental energy demand which was met by feeding ketoacids into glycolysis and TCA cycle.

The measured level of Ammonia also in turn signifies the decreased level of Glycogen might promote breakdown of Glycogen. The decreased Oxygen uptake and increased Lactic acid production in fish also support this condition. It was observed that the elevation of Ammonia content was noticed when $\mathrm{T}$. mossambica was treated with cypermethrin.

\section{Urea}

The acute toxicity of the pesticide cypermethrin shows increase in urea content in the tissues of Heteropneustes fossils indicates active promotion of Nitrogen metabolism under cypermethrin stress. Urea production in tissues constitutes a physiological mechanism with an important role in detoxification to cope with stress situation. urea levels in Liver, muscle and gill tissues exposed to cypermethrin showed significant increased trend suggests that liver plays a major role in Nitrogen metabolism.

The urea cycle enzymes were present in liver where as the other tissues may not synthesize urea as the existence of urea cycle enzymes is doubtful in these tissues. (Campbell, 1961). Hence the urea content in other tissues is a result of vascular mobilization from the liver as urea has high solubility and is known to pass readily through most of internal biological membranes (Watts and Watts, 1974). It was reported an increase in the urea content in T.mossambica also noticed when treated with pyrethroids (Radhaiah, 1988). It also signifies the increase in urea level in turn shows the conversion of toxic Ammonia into non toxic urea. The promotion of proteolysis indicates enhanced transamination i.e., elevated Ammonia levels may be 
the reason for increase in the urea content in liver and muscle tissues as alternative for detoxification process.

The author is grateful to University Grants Commission (SERO) for sanctioning Minor research Project (MRP- 7095/16, Dt. 14-9-2018) to carry out the Research Project Work.

\section{REFERENCES}

1. Ansari BA. Kumar (1988), Cypermethrin toxicity effect on the carbohydrate metabolism of a Indian Catfish, Heteropneustes fossils, Sci. Total. Environ, 72: 161-166.

2. Abidi, R. (1986). Studies on the toxicity of certain pesticides on fishes. Ph.D., Thesis, Allahabad University, Allahabad, India.

3. Aldridge, W.N. (1981). Organophosphorous compounds molecular basis for the biological properties. Sci. Prog. Oxf.,67; 131-147.

4. Begum, G, (2004). Carbofuran insecticide induced biochemical alterations of liver and muscle tissues of the fish clarias batrachus (Linn) and recovery response. Aquatic Toxicology, 6666:83-92.

5. Bessaman, S.P. and A,N. Bessaman; The cerebral and peripheral uptake of ammonia in liver disease with a hypothesis for the mechanism of hepatic Coma. J.Clin.Invest, 34:4(1955).

6. Calabrese, A, F.P. Thurberg, and E. Gould (1977). Effects of Cadmium, mercury and silver on marine animals. Mar.Fish.Rev., 39:5-11.

7. Campbell, J.W: Nitrogen excretion.In: comparative animal physiology. (Ed. Process. CL), Saunders Co., London, 279-316.(1976).

8. Chandravathy, M.V. Reddy, S.L.N. (1994). Invivo recovery protein metabolism ingill and brain of freshwater fish, Anabas Scandens after exposure to lead nitrate. J. Environ.Biol. 1; 75-82.

9. Colowick, S.P. and N.O.Kaplan, New York, 3:501 (1957)

10. Das, B.K and S.C. Mukherjee (2000). Chronic toxic effects of quinalphos on some biochemical parameters in Labeo rohita(Ham.). Toxicology Letters, 114(1-3):11-8.,
11. David, M. Musigeri S.B, Shivakumar R, Philip G.H (2004). Response of cyprinus carpio (Linn) to sublethal concentration of cypermethrin; alterations in protein metabolic profiles. Chemosphere 576: 347- 352.

12. El-Gendy, K.S., N.M. Aly, E. Rashwann and A.H, El-Sebae (1998). Biochemical targets affected by sublethal doses of cypermethrin. Toxicology Letters, 95:143.

13. Fernandes, M.N. and Mazon, A.F. 2003. Environmental pollution and fish gill morphology. In: Val, A.L. and Kapoor, B.G. Eds., Fish adaptation, Science Publisher, Enfield, 203231.

14. Gingerich, W.H. 1982. Hepatic toxicology of fishes. In: Aquatic toxicology. (Eds,: L.J. Weber). H. Ranen Press, New York. Pp. 55-105.

15. Ghosh, T.K. (1989). Influence of cypermethrin on the oxidative metabolism of fish Labeo rohita. Proc. Indian Acad. B, 55: 155-120.

16. Jayantha Rao, K. (1984). Histopathology as a diagnostic tool in evaluation of toxicity. Manual of Environ, Toxicol. Selected Lectures and Methods, pp. 35-40.

17. James, D.Y.E.C. Janice and M.R. Keith: Effects of chronic exposures to pesticides in animal systems (Eds,Janice, E.C. and James D.Y)Raven Press, New York (1982).

18. Kabeer, A.S.I: Studies on some aspects of problem metabolism and associated enzye system in the freshwater telcost, Tilapia mossambica (Peters) subjected to malathion exposure, P.hD. Thesis, S. V. University, Tirupati, India.

19. Lowry, O.H., N.J. Roseberg, A.L. Farr and R.J. Randall; Protein measurement with Folin Phenol reagent. J.B.D., Chem., 193: 265-275(1951)

20. Moore, S. And W.H. Stein: A modified ninhydrin reagent for the Photometric determination of Aminiacids and related compounds. J.B.D. chem.., 211: 907-913 (1954).

21. Philip, G.H, Reddy, P.M, Sridevi, G. (1995), cypermethrin induced invivo alterations in the carbohydrate metabolism of freshwater fish, Labeo rohita. Exotoxicol. Environ. Saf. 31: 173178. 
22. Prasad, T.A., T.Srinivas, and D.C. Reddy (1991). Modulations in nitrogen metabolism in the hepatic and neuronal tissues of fish, Tilopia mossambica exposed to atrazine. Biochem.Int. 23(2): 271-279.

23. Prasanth, M.S and M. David (2006). Changes in nitrogen metabolism of the freshwater fish. Cirrhinus mrigala following exposure to cypermethrin. J. Basic Clin. Physicol. Pharmacol., 17 (1): 63-70.
24. Sivakumar, R. (2005). Endosulphan induced metabolic alteration in freshwater fish, catla catla, Ph.D., thesis, Karnataka University, Dharwad, Karnataka, India.

25. Shakoori A.R, Zaheer S.A, Ahmed M.S. (1976). Effect of $\mathrm{mAL}$ thion, dieldrin and endrin and blood serum protein and free amino acid pool of chana punctatus (bloch), Pak. J.Zool. 8: 125-134. 